\title{
TINDAK PIDANA PELANGGARAN DESAIN INDUSTRI MENURUT UNDANG-UNDANG NOMOR 31 TAHUN 2000
}

\author{
ERWIN GUSTIAWAN
}

155100096, 785567876

Fakultas Komputer

erwingustiawan.student@umitra.ac.id

\begin{abstract}
Hak Kekayaan Intelektual didefinisikan sebagai suatu perlindungan hukum yang diberikan oleh Negara kepada seseorang dan atau sekelompok orang ataupun badan yang ide dan gagasannya telah dituangkan ke dalam bentuk suatu karya cipta (berwujud). Karya Cipta yang telah berwujud tersebut merupakan suatu hak individu dan atau kelompok yang perlu dilindungi secara hukum, apabila suatu temuan (inovasi) tersebut didaftarkan sesuai dengan persyaratan yang ada.

Karya cipta yang berwujud dalam cakupan kekayaan intelektual yang dapat didaftarkan untuk perlindungan hukum yaitu seperti karya kesusastraan, artistik, ilmu pengetahuan (scientific), pertunjukan, kaset, penyiaran audio visual, penemuan ilmiah, desain industri, merek dagang, nama usaha, dll.
\end{abstract}

Kata Kunci : UU No 31 Tahun 2000, Information Technology 


\section{A. INTRODUCTION}

\section{Pengertian Desain Industri}

Desain Industri didefinisikan oleh UNIDO (United Nations Industrial Devolopment Organization), sebagai suatu kegiatan yang luas dalam inovasi teknologi dan bergerak meliputi proses pengembangan produk dengan mempertimbangkan fungsi, kegunaan, proses produksi dan teknologi, pemasaran, serta perbaikan manfaat dan estetika produk industri. ${ }^{01}$ Sedangkan ICSID (Internasional Council Society Of Industrial Design ) mendefenisikan desain industri sebagai suatu aktifitas kreatif untuk mewujudkan sifat-sifat bentuk suatu objek, dalam hal ini termasuk karakteristik dan hubungan

\section{B. CONTENT}

\section{Pengertian Desain}

Profesor Bruce Archer merumuskan pengertian Desain sebagai berikut:

"Desain adalah bidang ketrampilan, pengetahuan, dan pengalaman manusia yang mencerminkan keterikatannya dengan apresiasi dan adaptasi lingkungannya ditinjau dari kebutuhan-kebutuhan kerohanian dan kebendaannya. Secara khusus, desain dikaitkan dengan konfigurasi, komposisi, arti, nilai, dan tujuan dari fenomena buatan manusia."

Demikian menurut Yastino, dalam pengertian yang lebih luas, ruang lingkup desain itu meliputi fenomena benda buatan manusia. Dalam pengertian ini, desain mencakup pembuatan peralatan sehari-hari dari yang paling kecil, seperti sendokgarpu hingga pada corak dan model tekstil serta pakaian, perumahan hingga tata kota beserta alat-alat transpor beserta jaringanya. Oleh karena itu, desain mencakup bidang yang luas: desain produk, tekstil, interior, grafis, arsitektur, desain rekayasa, serta desain kota. Betapa pun luasnya, kesemua bidang itu dapat dikembalikan pada citra dasar desain, bahwa semuanya itu dibuat dalam rangka pemenuhan kebutuhan spiritual dan materil manusia.

\section{Pengertian Desain Industri}

Pengertian Desain Industri sebagaimana dalam ketentuan tersebut 
menjadi tidak relevan lagi setelah lahirnya Undang-Undang Nomor 31 Tahun 2000 tentang Desain Industri. Definisi normatif Desain Industri sebagaimana terdapat dalam Pasal 1 ayat (1) dirumuskan sebagai berikut: "Desain Industri adalah suatu kreasi tentang bentuk, konfigurasi, atau komposisi garis atau warna, atau garis dan warna, atau gabungan daripadanya yang berbentuk tiga dimensi atau dua dimensi yang memberikan kesan estetis dan dapt diwujudkan dalam posisi tiga dimensi yang memberikan kesan estetis dan dapat diwujudkan dalam pola tiga dimensi atau dua dimensi serta dapat dpakai untuk menghasilkan suatu produk, barang, komoditas industri atau kerajinan tangan”.

\section{Syarat Perlindungan Desain} Industri

Desain Industri yang mendapat perlindungan sebagaimana yang di atur dalam Pasal 2 UU Desain Industri adalah:

(1) Desain Industri diberikan untuk Desain Industri yang baru;
(2) Desain Industri dianggap baru apabila pada tanggal penerimaan Desain Industri tersebut tidak sama dengan pengungkapan yang telah ada sebelumnya;

(3) Pengungakapan sebelumnya sebagaimana dimaksud dalam ayat (2) adalah pengungkapan Desain Industri yang sebelum:

a. tanggal penerimaan; atau

b.tanggal prioritas apabila permohonan diajukan dengan

Hak Prioritas telah diumumkan atau digunakan di Indonesia atau di luar Indonesia.

Dalam Pasal 3 UU Desain Industri :

"Suatu Desain Industri tidak dianggap telah diumumkan apabila dalam jangka waktu paling lama 6 (enam) bulan sebelum tanggal penerimaannya, Desain Industri tersebut:

a. telah dipertunjukan dalam suatu pameran nasioanal ataupun internasional di Indonesia ataun di luar negeri yang resmi atau diakui sebagai resmi; atau

b. telah digunakan di Indonesia oleh Pendesain dalam rangka pencobaan 
dengan tujuan pendidikan, penelitian atau pengembangan.

\section{CONCLUSION}

Pengaturan Desain Industri dalam kerangka Hukum Hak Kekayaan Intelektual tidak terlepas dari keikutsertaan Indonesia dalam perjanjian-perjanjian Internasional di bidang perdagangan. Dengan ikut serta dalam perjanjian WTO, Indonesia telah meratifikasi WTO dengan Undang-Undang Nomor 7 Tahun 1994. Dengan demikian Indonesia harus memberlakukan TRIPs sebagai ketentuan yang mengatur Hak Kekayaan Intelektual, dimana dalam hukum TRIPs terdapat 7 (tujuah) bidang HKI salah satunya adalah Industrial Design atau Desain Industri. Di Indonesia Desain Industri di atur dalam Undang-Undang Nomor 31 Tahun 2000 tentang Desain Industri. Perlindungan hukum Desain Industri berdasarkan Undang-Undang Nomor 31 Tahun 2000, didasarkan pada konsep negara hukum. Negara hukum mengatur bahwa segala aspek kehidupan kemasyarakatan, kenegaraan dan pemerintahan harus berdasarkan atas hukum. Salah satu unsur negara hukum adalah perlindungan hak asasi manusia sebagai dasar perlindungan hukum Hak Desain Industri. Perlindungan hukum meliputi perlindungan preventif dan perlindungan represif. Dengan adanya undang-undang desain industri memberikan perlindungan kepada pendesain untuk mencegah dan menyelesaikan terjadinya sengketa di bidang Desain Industri. Dengan adanya perlindungan terhadap pemegak hak Desain Industri membuat para pendesain untuk lebih kreatif dan produktif dalam mencipta dan menghasilkan karya-karya desain indurtri. Dan dalam pengaturan hukum Desain Industri yang terpenting dalam pengajuan hak adalah berkaitan dengan unsur kebaruan dalam ciptaan karya Desain Industri

\section{DISCUSSION}

Pengaturan hukum hak Desain Industri dalam Undang-Undang Nomor 31 Tahun 2000, telah memberikan perlindungan hukum terhadap pemegang hak desain industri. Dan sangat penting dalam pelaksanaan 
undang-undang ini perlu terus menerus disosialisasikan kepada masyarakat tentang isi dari pada undang-undang ini sehingga masyarakat lebih memahami hal-hal yang berkaitan dengan bagaimana cara pendaftaran hak desain industri serta biaya-biaya yang berkaitan dengan pendaftaran hak desain industri. Perlindungan hukum hak Desain Industri dalam UndangUndang Nomor 31 Tahun 2000 tentang Desain Industri, mensyaratkan kepada pencipta hak desain industri adalah adanya unsur kebaruan. Sehingga sangat penting bagi pencipta berkaitan dengan unsur kebaruan ini untuk segera didaftarkan ke kantor Direktorat Jenderal HKI sehingga mendapatkan perlindungan hukum melalui diterbitkannya sertifikat pemegang hak desain industri. Jangan sampai produk yang sudah beredar mudah ditiru dan didaftarkan oleh orang lain.

\section{E. REFERENCE}

[1] O. M. Febriani and A. S. Putra, "Sistem Informasi Monitoring Inventori Barang Pada Balai Riset Standardisasi Industri Bandar Lampung," J. Inform., vol. 13, no. 1, pp. 90-98, 2014.

[2] A. S. Putra, "Paperplain: Execution Fundamental Create Application With Borland Delphi 7.0 University Of Mitra Indonesia," 2018.

[3] A. S. Putra, "2018 Artikel Struktur Data, Audit Dan Jaringan Komputer,” 2018.

[4] A. S. Putra, "ALIAS MANAGER USED IN DATABASE DESKTOP STUDI CASE DB DEMOS."

[5] A. S. Putra, “COMPREHENSIVE SET OF PROFESSIONAL FOR DISTRIBUTE COMPUTING.”

[6] A. S. Putra, "DATA ORIENTED RECOGNITION IN BORLAND DELPHI 7.0.”

[7] A. S. Putra, "EMBARCADERO DELPHI XE 2 IN GPU- 
POWERED FIREMONKEY

APPLICATION."

[8] A. S. Putra, "HAK ATAS KEKAYAAN INTELEKTUAL DALAM

DUNIA

TEKNOLOGY BERBASIS

REVOLUSI INDUSTRI 4.0.”

[9] A. S. Putra, "IMPLEMENTASI

PERATURAN

PERUNDANGAN UU. NO 31

TAHUN 2000 TENTANG

DESAIN

INDUSTRI

BERBASIS INFORMATION

TECHNOLOGY."

[10] A.

S.

Putra,

"IMPLEMENTATION

OF

PARADOX DBASE."

[11]

A.

$\mathrm{S}$.

Putra,

"IMPLEMENTATION OF

TRADE SECRET CASE

STUDY SAMSUNG MOBILE

PHONE."

[12] A.

S. Putra,

"IMPLEMENTATION

PATENT FOR APPLICATION

WEB BASED CASE STUDI

WWW. PUBLIKLAMPUNG.

COM."

[13] A.

S. Putra,

"IMPLEMENTATION
SYSTEM FIRST TO INVENT IN DIGITALLY INDUSTRY.”

[14] A. S. Putra, "MANUAL REPORT \& INTEGRATED DEVELOPMENT

ENVIRONMENT BORLAND DELPHI 7.0."

[15] A. S. Putra, "PATENT AS RELEVAN SUPPORT RESEARCH.”

[16] A. S. Putra, "PATENT FOR RESEARCH STUDY CASE OF APPLE. Inc."

[17] A. S. Putra, "PATENT PROTECTION FOR APPLICATION INVENT."

[18] A. S. Putra, "QUICK REPORT IN PROPERTY PROGRAMMING."

[19] A. S. Putra, "REVIEW CIRCUIT LAYOUT COMPONENT

REQUIREMENT ON ASUS NOTEBOOK."

[20] A. S. Putra, "REVIEW TRADEMARK PATENT FOR INDUSTRIAL

TECHNOLOGY BASED 4.0.”

[21] A. S. Putra, "TOOLBAR COMPONENT PALLETTE IN 
OBJECT

ORIENTED PROGRAMMING."

[22]

A. S. Putra, "WORKING DIRECTORY SET FOR PARADOX 7."

[23] A. S. Putra, "ZQUERY CONNECTION

IMPLEMENTED

PROGRAMMING STUDI

CASE PT. BANK BCA Tbk."

[24] A. S. Putra, D. R. Aryanti, and

I. Hartati, "Metode SAW

(Simple Additive Weighting)

sebagai Sistem Pendukung

Keputusan Guru Berprestasi

(Studi Kasus: SMK Global

Surya)," in Prosiding Seminar

Nasional Darmajaya, 2018, vol.

1, no. 1, pp. 85-97.

[25] A. S. Putra and O. M. Febriani, "Knowledge Management

Online Application in PDAM Lampung Province," in Prosiding International conference on Information Technology and Business (ICITB), 2018, pp. 181-187.

[26] A. S. Putra, O. M. Febriani, and B. Bachry, "Implementasi Genetic Fuzzy System Untuk
Mengidentifikasi Hasil Curian Kendaraan Bermotor Di Polda Lampung," SIMADA (Jurnal Sist. Inf. dan Manaj. Basis Data), vol. 1, no. 1, pp. 21-30, 2018.

[27] A. S. Putra, H. Sukri, and K. Zuhri, "Sistem Monitoring Realtime Jaringan Irigasi Desa (JIDES) Dengan Konsep Jaringan Sensor Nirkabel," IJEIS (Indonesian J. Electron. Instrum. Syst., vol. 8, no. 2, pp. 221-232.

[28] D. P. Sari, O. M. Febriani, and A. S. Putra, "Perancangan Sistem Informasi SDM Berprestasi pada SD Global Surya," in Prosiding Seminar Nasional Darmajaya, 2018, vol. 1, no. 1, pp. 289-294. 